\title{
Modern Trends in Education - Enrichment or Threat to the Social Structure
}

\author{
Ms. Vaibhavi Gawarikar \& Ms. Sangeeta Poddar \\ Designation: Academic AssociatesInstitution: School of Liberal Arts \& Education, Navrachana University, \\ Vadodara.
}

\begin{abstract}
The Indian Education System is driven by strong forces of preserving the constitutional mandate of creating a society enriched with Indian values, culture and ethics on one hand and the pull towards reaching international standards which promote science and technology driven society on the other. The importance to create $21^{\text {st }}$ Century citizens has been identified as a strong need, but this acknowledgement is getting implemented in a manner which predicts to create educational inequality in the society- which means going against our national and constitutional goals. The present paper discusses this issue by throwing light on various companies that are creating expensive educational packages and making schools a market for their products. The elite schools who can afford the same, move levels higher than the mediocre schools - thus widening the already existing gap. The question is, are we moving in the right direction?
\end{abstract}

\section{INTRODUCTION}

It is the second decade of the new millennium and a time to rightfully acknowledge the fact that the world today is and the one ahead would be exponentially different in its physical, social, psychological, cognitive as well as philosophical structures. These structural modifications embody not only the higher echelons but also percolates down to each individual. The observable transitions as we moved from the $20^{\text {th }}$ to the $21^{\text {st }}$ century are not only at the cultural, economical and technological levels but also at a micro- cognitive and affective level. A scan into the life styles of the two centuries would make the transforming thought processes vividly evident. The rigid-formatted-restricted lives as well as minds are eventually getting replaced by open-flexible-active ones. Solutions are supposed to be arrived in the next instant problems are identified. Biologically too human minds are adapting to this continuously soaring aspirations. Somehow, be it positive or negative the wheels have turned on and we are at a go climbing higher and higher.Today we are immersed in a bewildering array of subjects, extra-curricular activities, multiple intelligence theories and pedagogies. It is immensely difficult to cut through the chatter and address the core questions: What skills should we equip our children with, so that they may excel in life, and be fruitful contributors to society? How do we empower today's youth to cope with the ocean of knowledge around them, and achieve in the hyper-competitive, technologydriven, global economy? The answer lies in the term "21st Century Skills", an umbrella of well-identified skills that we must equip our children with [1].

\section{What are $21^{\text {st }}$ Century Skills?}

The 21st century skills are a set of abilities that students need to develop in order to succeed in the information age. The Partnership for 21st Century Skills (P21), a leading public-private partnership founded in 2002, in its effort to position 21 st century readiness in the US K-12 education, classified $21^{\text {st }}$ century skills as:

Learning and Innovation Skills: Creativity and Innovation, Critical Thinking and Problem Solving, Communication and Collaboration (the "4 Cs")

Information, Media and Technology Skills: Information Literacy, Media Literacy and ICT Literacy

Life and Career Skills: Flexibility and Adaptability, Initiative and Self Direction, Social and Cross-cultural Skills, Productivity and Accountability [2]Several governments, multinationals, industry experts, academics and educationists have worked together in various groups to define them. These $21^{\text {st }}$ Century skills integrated with the present curriculum can be termed as the "modern education system". Closer to home in India, the movement towards modernizing education system is very nascent. Although there is recognition among parents and teachers that students need new kinds of skills for the new era, like digital literacy and information fluency, there is little awareness about a well-defined framework being available for learning and teaching these new skills [1]. The Central Board of Secondary Education (CBSE) does have theoretical inputs to promote $21^{\text {st }}$ century skills among the learners, but the implementation is at an introductory level and not much has been achieved yet. Some of the elite and good schools of the country have identified the importance of these skills and either making changes within their school system to incorporate the same or are taking support from external bodies to achieve them. Thus a new trend in education is about to begin - allowing external 
organizations to enter our schools and helping them flourish with a share in the profit the private schools were already earning.

\section{MODERN TRENDS IN EDUCATION SYSTEM}

Modern Education System caters to the present and the future needs of the nation and its citizens. Varied innovations are enriching the ongoing educational process throughout the world. Some of the modern trends in education followed in India are Flipped classroom, STEM education, Digital Education, Concept Schooling etc.

\section{FLIPPED CLASSROOM}

The idea of flipped classrooms originated in high schools in the United States a few years ago. Flipped classroom is an instructional strategy and a type of blended learning that reverses the traditional learning environment by delivering instructional content, often online, outside of the classroom. It moves activities, including those that may have traditionally been considered homework, into the classroom. In a flipped classroom, students watch online lectures, collaborate in online discussions, or carry out research at home and engage in concepts in the classroom with the guidance of a mentor [3].

This concept of Flipped classroom is implemented by 41 most innovative K-12 Schools in America. In India its major applications are in universities like Delhi University's School of Open Learning (SOL), The Indian School of Business (ISB), SP Jain Institute of Management and Research (SPJIMR). In Vadodara, the Navrachana chain of schools has introduced this concept in their classrooms [4].

\section{STEM Education}

STEM is a curriculum based on the idea of educating students in four specific disciplines — science, technology, engineering and mathematics - in an interdisciplinary and applied approach. Rather than teach the four disciplines as separate and discrete subjects, STEM integrates them into a cohesive learning paradigm based on real-world applications. What separates STEM from the traditional science and math education is the blended learning environment and showing students how the scientific method can be applied to everyday life [5].STEM programs have been developed by the U. S. Department of Education and the National Science Foundation, in order to promote an integrated educational program for the K-12 students with special emphasis on the STEM subjects. A variation of STEM is STEAM, which includes an 'A' for art and design. Artistic design is becoming an important part of STEM education since creativity is an essential part of innovation [6]. The basic aim underlying the STEM curriculum [7] is to develop the abilities to inquire, think, investigate, and innovate, within its learners. STEM skills are in high demand in every field. Some of the primary STEM skills are Problem-solving, Innovative thinking, Critical Thinking, Communications, Productive teamwork, Generating multiple ideas and Decision-making.In India, STEM education program has been operating in various schools like Gitanjali Senior School, Hyderabad; Anand Niketan Schools, Gujarat; Saint MSG, Haryana; Sri Laxmi School, Kurnool; Neerja Modi School, Jaipur; Navrachana School, Vadodara [8].

Apart from this, the Academy of Stem India is also planning to open 100 schools over the next 10 years across the country that would attract an investment of Rs 2,500-3,000 crore [9].

\section{DIGITAL EDUCATION}

With the development of Internet, mobile phones, mobile apps, tablets, laptops, and other modern devices, things are becoming more and more digitalized in today's world. Even the classroom teaching is becoming modernized with the use of digital methods such as PPTs, video presentations, e-learning methods, practical demos, online training and other digital methods or platforms.Many of the Indian schools are using "Smart Class" to enhance their teaching learning process. This has not only been adopted by the elite and mediocre schools but is also planned to be implemented in government run schools. Initiatives such as eeducation, e-basta, Nand Ghar which will impart education using technologies including smartphones, mobile apps and internet services have already begun in far-flung areas of the country [10].In order to transact these innovate trends of modern education, schools of India are taking the support of varied companies that are designing educational packages. STEM education providers in India are ATLAB STEM Academy, Think Labs, India Stem Foundation, Eductech, Stem Learning, Stem Labs, Creya and many more [11]. The Creya XEL Program offered in schools charge as much as 40-50 lakhs. Some of the companies involved in Smart education and e-learning in India are Educomp solutions, Abode Systems, Blackboard, Scholastic, Smart Technologies, Cisco Systems, INTEL and many more. The annual revenues earned by these companies range from 5 lakhs to crores [12]. With support from Qualcomm ${ }^{\circledR}$ Wireless Reach ${ }^{\mathrm{TM}}$ Initiative, Sesame Workshop in India is trying to bridge the education gap by providing innovative and engaging content that is integrated into the prescribed curriculum through games on digital devices [10]. These educational packages are specifically designed by experts from different fields which involve a lot of research work and physical resources, thus making the whole 
package extremely expensive. These packages are sold to public and private institutions at a high price. Thus, it can be rightly stated that the education sector is now being converted into a big market, making 'education' a priced product.As far as India is concerned, it is only the elite schools that can afford these packages and provide an extra impetus to its students in terms of either development of the $21^{\text {st }}$ Century Skills or ICT efficiency. Majority of the Indian Schools fall under the mediocre group, who automatically get refrained from these so-called " $21^{\text {st }}$ Century Educational Packages". Thus, in the name of providing modern education, we may actually harm the social structure in the long run. Making the qualitative education reserved for the rich and barring the poor from the same, we are progressing towards a situation which can be termed as "educational inequality"- something which is in stark contrast to the aims of the Indian education.

\section{AIMS OF INDIAN EDUCATION}

The Resolution on Scientific Policy adopted by government of Jawaharlal Nehru emphasized the development of "high-quality scientific education", based on which the National Policy of Education (NPE, 1968) was framed. The implementation of this policy when later reviewed by various experts and academicians gave away a major loophole -“even the highly educated and successful youths lacked humane values and ethics". This concern resulted into the restructuring of the National Policy [13]. The evolved NPE, 1986 thus put forward the following aims:

- Development of Democratic Values in the People

- National Integration

- Development of Physical Resources

- Development of Human Resources

- Development of Social, Moral and Spiritual Values [14]

Apart from these aims, a special emphasis was made on the "removal of disparities and to equalize educational opportunities".

Therefore, the above discussion gives rise to certain broad questions.

1. Do these modern trends of education align to our national goals? Are we not moving back to the same ideology that was identified as a loophole and caused the restructuring of the National Education Policy? As stated by the RBI governor Raghuram Rajan "middle class jobs are disappearing either because of technology or globalization" [15]. Are we in a path of creating a "social imbalance" by allowing only the higher echelons to get the best?

2. These trends are adopted by developed countries having capitalist economies that aim for profit. While India follows a mixed economic system giving equal importance to social welfare. Since the context differs for India, should we blindly follow the trends that are relevant for other countries? For example STEM education was specifically introduced by the U.S.A government when they found low achievements in Math and Science among their students. Looking into the needs of our education, CCE was introduced in India in 2009. After a few training programs the teachers are left to implement it with inadequate knowledge about it, thus causing more harm. Instead of strengthening the existing system we are swayed away by more new and complex innovations happening in the name of modern education.

Giving recognition to the fact, that every nation should equally climb the global ladder, India cannot stay behind. It has to adopt the modern trends of education, but needs to devise ways and means to propagate this kind of education "equally" for all Indians across all schools, only then the national aims of education can be replenished.

3. All these modern trends require the development of higher order thinking skills among students. Are our schools, teachers as well as students ready for this big change? There are various issues like maturity of the school children, preparation of teachers to provide this kind of high quality teaching, physical and financial resources etc. to be resolved before taking up these trends.

Thus, even if we want to imbibe these elements into our school curriculum, it seems to be a forlorn task. Moreover, schools should primarily focus on the development of lower order thinking skills by strengthening the fundamentals of the subjects. Only then a strong foundation for the students, transiting towards higher education can be created. Therefore, the task of modernizing education should be taken-up by the higher education sector of the country. The process may begin at the school level in an ostensible way by making some of the essential elements an integral part of the syllabus. 


\section{REFERENCES}

[1] Narsipur, P. (2013). Advocacy, $21^{\text {st }}$ century skills for our children. Educast. Retrieved on June 6, 2016 from

[2] http://www.creyalearning.com/resources/Educast\%20July\%20-13_Creya.pdf

[3] P21 Framework definitions. (2015). The Partnership for $21^{\text {st }}$ Century Learning. Retrieved on May 20, 2016 fromhttp://www.p21.org/storage/documents/P21_Framework_Definitions.pdf

[4] Tuli, S. (2015). How the flipped classroom model can work in India. The Financial Express. Retrieved on June 10, 2016 from http://www.financialexpress.com/article/industry/jobs/how-the-flippedclassroom-model-can-work-in-india/69072/

[5] N.A, (2014, August 14). DU school of open learning to adopt flipped classroom method. The Times of India. Retrieved on June 10, 2016 from

[6] http://timesofindia.indiatimes.com/home/education/news/DU-school-of-open-learning-to-adopt-flippedclassroom-method/articleshow/40858046.cms

[7] Hom E. J. (2014, February 11). What is Stem Education? Live Science Contributor. Retrieved on June 8, 2016 from http://www.livescience.com/43296-what-is-stem-education.html

[8] Wikipedia, the free encyclopedia (2016, June 12). Science, technology,

[9] engineering, and mathematics. Retrieved on June 10, 2016 from

[10] https://en.wikipedia.org/wiki/Science,_technology,_engineering,_and_mathematics

[11] Jolly, A. (2013, August 20). How to get your school ready for STEM this year? Mind Shift. Retrieved on June 8, 2016 from http://ww2.kqed.org/mindshift/2013/08/20/how-to-get-your-school-ready-for-stemthis-year/

[12] N.A. In school programs 2013. kindle experiential learning Pvt. Ltd retrieved on June 10, 2016 from http://www.creyalearning.com/gallery/gallery.html

[13] N.A.(2015, January 18). Stem India plans Rs 3,000 crore on 100 schools. The Economic Times, Education. Retrieved on June 10, 2016 from http://articles.economictimes.indiatimes.com/2015-0118/news/58200604_1_100-schools-crore-bikaner

[14] Banerjee, S. (2015). Tech companies have to take the lead and help enable a strong ecosystem. The India Today Group. Retrieved on June 10, 2016 from http://www.dailyo.in/user/8626/bongchild

[15] India's Largest Hands-On Science \& Technology Education Provider. Thinklabs. http://www.thinklabs.in/

[16] Edustars Survey Report (2012). YS Research, Your Story Media Pvt. Ltd. Retrieved on June 8, 2016 from http://yourstory.in/research

[17] National Council of Education Research and Training. Context and Concerns. NCERT. Retrieved on June 12, 2016 from http://www.ncert.nic.in/html/pdf/schoolcurriculum/ncfsc/ch1.pdf

[18] Kumar, S. (2015, n,d). What is the National Objectives of Education in India? PublishYourArticles.Net. Retrieved on June 10, 2016 fromhttp://www.publishyourarticles.net/knowledge-hub/education/what-isthe-national-objectives-of-education-in-india/5207/

[19] Rajan, R. (2015, June 10).Middle-class job loss to tech creates anti-immigrant sentiment. The Times of India, pp. 1 